\title{
Study of the Fermentation Conditions of the Bacillus Cereus Strain ARY73 to Produce Polyhydroxyalkanoate (PHA) from Glucose
}

\author{
Akram R. Yasin ${ }^{1 *}$, Ithar K. Al-Mayaly ${ }^{1}$ \\ 1 Department of Biology, College of Science, University of Baghdad, Iraq \\ * Corresponding author's email: akram4ecology@gmail.com
}

\begin{abstract}
Polyhydroxyalkanoates (PHAs) have gained much attention as biodegradable polymers, many efforts are being made to minimize the cost of PHAs by finding cheap carbon source depending on the type of microorganism and fermentation conditions. The aims of this study were to evaluate the effects of different glucose concentrations and other important conditions on the PHA production by Bacillus cereus isolated from soil. Polyhydroxyalkanoates PHAs accumulated by soil microorganisms were examined by screening the isolated bacteria using Sudan B Black and Nile Blue staining process. A Gram positive strain was identified using the 16s rRNA gene, deposited in the NCBI GenBank sequence database. Different growth conditions (favorite glucose concentrations 1-8 \% $(\mathrm{w} / \mathrm{v})$, temperatures and $\mathrm{pH})$ were tested and the growth parameters (sugar consumption, cell counting and Cell Dry Weight CDW) were studied. The extracted polymers were analyzed and characterized using an FTIR spectrophotometer followed by a GC-MS analysis. The pure bacterial strain isolated from soil was deposited in the NCBI GenBank database B. cereus strain ARY73, which showed significant black colored granules (or dark blue) using Sudan B Black stain, it also showed positive to Nile blue A as a high indicator stain for PHA accumulation. B. cereus ARY73 showed high production of PHA using (w/v): $2 \%$ glucose and $1 \%$ nitrogen source at $35^{\circ} \mathrm{C}$ and pH7 yields 79\% per Cell Dry Weight and $96 \mathrm{~h}$ of incubation. The extracted polymers were analyzed and characterized using an FTIR spectrophotometer confirming the PHA structure. The FTIR spectrophotometer, followed by a GC-MS analysis indicated the Scl-co-mcl PHA structure. This research demonstrates that the isolated strain B. cereus ARY73 was a good candidate for PHA production with a better quality for use in biomedical and other applications. The use of biopolymer in soil, enhanced the accumulation of the microorganisms (such as bacteria) capable of degrading biopolymer or biodegradation by-products yields by other species which were isolated in this study and demonstrated their efficiency in producing biopolymers.
\end{abstract}

Keywords: Polyhydroxyalkanoates, PHA, Bacillus cereus, biopolymer, glucose.

\section{INTRODUCTION}

Polyhydroxyalkanoates (PHAs) as a biodegradable material are considered as alternative biopolymers for petroleum-derived plastics [Kourmentza et al., 2017]. Synthetic plastics which have been extensively used since many decades, known as non-degradable plastics, are potent environmental toxic pollutants and have accumulated in the environment. The most abundant member of the PHAs family, known as poly-3-hydroxybutyrate (P3HB), a homopolymer of 3-hydroxybutyrarte, similar in properties to polypropylene. Poly-3-hydroxyvalerate (PHV) is another member of the PHAs family with more flexible properties [Napathorn, 2014]. PHA are thermoplastic polyesters produced by bacteria intracellularly as carbon and energy storage and capsulated as granules in cytoplasm [Radivojevic et al., 2016]. PHA was found to accumulate in large number of bacteria e.g. Ralstonia eutrophes, Pseudomonas putida, P. fluorescens, Bacillus spp. and Escherichia Coli [Poltronieri and Kumar, 2017; Pagliano et al. 2017].

Meanwhile, PHAs have been attracting global attention as a biomaterial polymer, renewable, and biodegradable alternatives to a synthesized petrochemical plastics [Rhee and Park, 2021]. 
Many Prokaryotic organisms produce polyhydroxyalkanoates (PHA), including gram negative and gram positive bacteria, when carbon source (e.g. glucose, lactose, galactose) is available in excess as reserve material with a limitation of nutrients essential for growth such as nitrogen, phosphorous, magnesium or sulfur [Kamravamanesh and Herwig, 2018]. Under aerobic conditions these microorganisms decompose PHAs resulting in final products, i.e. carbon dioxide and water. Under anaerobic conditions, they result in carbon dioxide and methane [Shrivastav et al., 2011]. Under carbon limitation conditions, microorganisms use PHA depolymerase and other enzymes to hydrolyze accumulated PHA intracellularly for the growth and survival [Mitra et al., 2020].

PHA synthase is the key enzyme responsible for polymerization of PHA, and encoded by the phaC genes. PHA synthases are categorized into four main classes: class I, III and class IV prefer synthesizing scl-PHA, while Class II PhaC enzymes prefers synthesizing mcl-PHA (mediumchain-length). Some exceptions were observed; in literature it was reported that several class I PhaCs may produce scl-mcl-PHA. PhaCAc is considered as one of the most successful enzymes used for scl-mcl-PHA production, while Class IV PHA synthases from Bacillus cereus type (IVc) [Chee et al., 2012; Mezzolla and Poltronieri, 2018].

Recombinant microorganisms could allow high cell density and faster growth with high levels of PHA production The most standard organism used in genetic engineering is $E$. coli which has been shown to be advantageous for PHAs production [Mezzolla and Poltronieri, 2017]. Most PHA producing bacteria can use simple sugars. Generally, substrates can be divided into three categories which are simple sugars (monosaccharides), triacylglycerol and hydrocarbons. The cost of the carbon source estimated at approximately $50 \%$ for the entire process of PHAs production [Khosravi-Darani et al., 2013].

The PHAs products are not toxic to cells and soft tissues with some diverse properties to contribute in medical applications [Koller, 2018]. High cost of PHA production is considered as the main challenge for scientists. Many efforts of minimizing the cost of PHA have been made by finding a cheap carbon source, such as dairy waste, lubricating and edible oil waste and agriculture waste [Surendran et al., 2020]. From previous literature it is known that only few microorganisms are able to produce PHA from lactose.
The purpose of this study was to evaluate the effects of different amounts of the carbon source (glucose) at different temperatures on the growth and PHAs yield by the isolated bacteria.

\section{MATERIALS AND METHODS}

\section{Isolation of PHA producing bacteria}

In order to isolate the PHA producing bacteria, bioplastic sheets made of PHA granules manufactured by BASF (ecovio, Germany), were buried in a garden soil located in the city of Baghdad/Iraq at the depth of $(5-10 \mathrm{~cm})$ and allowed to be degraded. Two months later, the samples of the degraded polymers mixed with soil were collected and transferred immediately by a sterilized plastic bags to a laboratory (department of Biology, college of science, University of Baghdad). A serial dilution technique was performed, aseptically a solution of $1 \mathrm{ml}$ was poured on the nutrient agar medium (Oxoid, UK) contains $5 \%(\mathrm{w} / \mathrm{v})$ of glucose and incubated (Precision, USA) at $37^{\circ} \mathrm{C}$ for 3 days.

The bacterial colonies were subjected to a series of steps to obtain purified PHA producing strains by sub-cultured on polyhydroxyalkanoates medium (PM) agar by adding: $0.6 \mathrm{~g}$ of $\mathrm{K}_{2} \mathrm{HPO}_{4} \cdot 3 \mathrm{H}_{2} \mathrm{O} ; 0.2 \mathrm{~g}$ of $\mathrm{MgSO}_{4} \cdot 7 \mathrm{H}_{2} \mathrm{O} ; 0.2 \mathrm{~g}$ of $\mathrm{KH}_{2} \mathrm{PO}_{4} ; 0.2 \mathrm{~g}$ of $\left(\mathrm{NH}_{4}\right) 2 \mathrm{SO}_{4} ; 20 \mathrm{~g}$ of agaragar; $900 \mathrm{ml}$ distilled water and $2.0 \mathrm{ml} / \mathrm{L}$ of the trace element solution $\left(\mathrm{g}^{-1}\right): 0.10 \mathrm{ZnSO}_{4} \cdot 7 \mathrm{H}_{2} \mathrm{O}$; $0.3 \mathrm{H}_{3} \mathrm{BO}_{3} ; 0.03 \mathrm{MnCl}_{2} .4 \mathrm{H}_{2} \mathrm{O} ; 0.2 \mathrm{CoCl}_{2} .6 \mathrm{H}_{2} \mathrm{O}$; $0.01 \mathrm{CuCl}_{2} \cdot 2 \mathrm{H}_{2} \mathrm{O} ; 0.03 \quad \mathrm{Na}_{2} \mathrm{MoO}_{4} \cdot 2 \mathrm{H}_{2} 0 ; 0.02$ $\mathrm{NiCl}_{2} \cdot 6 \mathrm{H}_{2} \mathrm{O} . \mathrm{pH}$ adjusted to 7.2 . The medium was autoclaved (LabTech, Indonesia) at $121{ }^{\circ} \mathrm{C}$, 15 psi for $15 \mathrm{~min}, 5 \mathrm{~g}$ of glucose (as the only source of carbon) was suspended in $100 \mathrm{ml}$ distilled water and separately autoclaved at $121{ }^{\circ} \mathrm{C}$ for 5 minutes (in order to prevent glucose from caramelization) [Javaid et al., 2020]. All cultures were incubated at $37^{\circ} \mathrm{C}$ for 3 days.

\section{Screening of PHA producing bacteria}

Streaked isolates on the PM medium agar (glucose) plates were examined for PHA production by using Sudan B Black staining (Merck, Germany) as described by Kumar et al. [2018], smears were examined using light microscope (Olympus, Japan) under $(100 \times)$ oil immersion objective. Another specific stain method was conducted using Nile Blue A stain (Merck, Germany) which was 
performed according to Legat et al. [2010], all slides were examined at $460 \mathrm{~nm}$ using fluorescence microscope (ZEISS AXIOLAB, GERMANY) [Yasin and Al-Mayaly, 2020].

Sudan B Black staining solution was prepared by adding the dye in $70 \%$ ethanol mixed well and filtered. The staining procedure was as follows: $10 \mathrm{ml}$ of sample was centrifuged, using s loop cell pellet was taken and placed on dry slide, dispersed in the clockwise and anticlockwise direction, and allowed to air dry, then it was fixed by heating. The fixed smear was flooded with Sudan B Black staining solution and allowed to react for 15 minutes. After draining off the excess stain and drying, it was rinsed with xylene and dried again. Then, it was counterstained by safranin for 10 seconds, immediately rinsed with water and left to dry. The slide was tested under oil immersion objective. The Nile Blue A staining procedure included: after fixed the smears (as mentioned above), the slides were stained with $1 \%$ of Nile Blue A aqueous solution and kept at $55^{\circ} \mathrm{C}$ for 10 minutes, washed with tap water. The smears were stained with $8 \%$ aqueous acetic acid for 1 minute, washed with water, dried, remoistened with water and covered with cover slip. The slides were examined at $460 \mathrm{~nm}$ using fluorescence microscope.

\section{Characterization of the bacterial isolates}

The morphological and physiological properties of the isolated bacteria (L1-a) were investigated according to Bergey's Manual of Determinative Bacteriology. The identity of the isolate was determined by sequence analysis of the 16s rRNA gene. Genomic DNA was isolated from bacterial growth according to the protocol of Wizard Genomic DNA Purification Kit, Promega. PCR product were processed for Sanger sequencing using an ABI3730XL automated DNA sequencer, by Macrogen Corporation - Korea. The results were analyzed using Geneious software version 11.1. [Kearse et al., 2012].

The amplification of 16s RNA gene of unknown bacterial species were fractionated on $1.5 \%$ agarose gel electrophoresis stained with Ethidium Bromide M: 100bp ladder marker. Lanes ARY73 resembles 1500bp PCR products.

27F Primer 5 '-AGAGTTTGATCCTGGCTCAG-3’

1429R Primer 5'-TACGGTTACCTTGTTACGACTT-3`
The obtained sequence from strain was deposited in the NCBI GenBank (National Center for Biotechnology Information) sequence database under accession number ARY73 MW362363 and compared with those stored in the GenBank database by using the BLAST (Basic Local Alignment Search Tool) program [Johnson et al., 2008]. On the basis of THE Blast analysis, the phylogenetic tree was prepared and constructed using phylogeny [Vogel et al., 2021].

\section{Effect of growth conditions on PHA production by selected Isolate}

The effect of carbon source concentration (w/v): low conc.: $1 \%, 1.5 \%, 2 \%, 2.5 \%$ and $3 \%$; high conc.: $4 \%, 6 \%$ and $8 \%$, initial $\mathrm{pH}(5,7$ and 9$)$, temperature $\left(25,30,35\right.$ and $\left.40{ }^{\circ} \mathrm{C}\right)$, and nitrogen concentrations $(0.5,1.0,1.25$ and $1.5 \mathrm{~g} / \mathrm{L})$ on the PHA production by the selected isolate was evaluated using a PM mineral medium according to Franz et al. [2012], (500 ml Erlenmeyer flask containing glucose), the addition of inoculum was $1 \%(\mathrm{v} / \mathrm{v})$ after grown overnight at $37^{\circ} \mathrm{C}, 150$ $\mathrm{rpm}$. All samples were incubated for 5 days in a shaking incubator (LabTech, Indonesia) $150 \mathrm{rpm}$, the results were then compared by measuring the sugar consumption (DNS), Cell counting, Cell Dry Weight (CDW) and the weight of extracted PHA, PHA\% quantified according to Eq. 1.

$$
\% P H A=\frac{P H A \text { weight }}{\text { Biomass dried weight }} \times 100
$$

\section{Monitoring of bacterial growth conditions and PHA yield}

\section{Cell counting}

Cell counting was performed by using the Hemocytometer method. Cell counting was measured every 24 h. $0.5 \mu \mathrm{l}$ of cell suspension were stained by Trypan Blue (Sigma Aldrich, Germany) and tested on Hemocytometer, viable cells were counted under microscope.

\section{Cell Dry weight}

Aseptically, $10 \mathrm{ml}$ of sample were taken in a glass centrifuge tube. The culture was centrifuged at $10,000 \mathrm{rpm}$ at $-4{ }^{\circ} \mathrm{C}$ for $15 \mathrm{~min}$, and the pellet was then dried in an oven at $55^{\circ} \mathrm{C}$ for $24 \mathrm{~h}$ and weighed [Getachew \& Woldesenbet, 2016]. 


\section{DNS Method (sugar consumption)}

The determination of sugar consumption was estimated by Di-Nitrosalicylic acid (DNS method) throughout each fermentation period according to the method described by Miller [Blandón et al., 2020]. This method gives a rapid estimation by measuring the total amount of reducing sugars in the hydrolysate.

Briefly, the calibration curve was done using glucose as standard ( 0 to $2 \mathrm{~g} / \mathrm{L}$ ). $500 \mu 1$ of supernatant, obtained by centrifugation, was added to $500 \mu 1$ of the DNS reagent (Sigma Aldrich, Germany) [DNS $1 \%(\mathrm{w} / \mathrm{v})$, phenol $0.2 \%(\mathrm{w} / \mathrm{v})$, Rochelle salt $40 \%(\mathrm{w} / \mathrm{v})$, and potassium disulfide $0.5 \%(\mathrm{w} / \mathrm{v})$ mixed with sodium hydroxide at $1.5 \%(\mathrm{w} / \mathrm{v})]$. These solutions were heated for $5 \mathrm{~min}$ in boiling water. Absorbance was measured at $540 \mathrm{~nm}$.

\section{PHA Extraction}

After being weighed, the dried pellet was washed once with ethanol and distilled water. PHAs were extracted by adding a mixture of 7 $\mathrm{mL}$ of hot chloroform (POCH, Poland) and $3 \mathrm{~mL}$ aqueous $\mathrm{NaOCl}$ solution (4\%) (Peros, Turkey), mixed vigorously by vortex (Labco, Germany). The mixture was centrifuged to obtain three separated layers. The lowermost layer was the PHA dissolved in chloroform. Nine-fold amount of ice-cold methanol was added for PHA precipitation and then allowed to evaporate at the room temperature [Ojha and Das, 2020].

\section{Analytical procedures}

\section{FTIR analysis for PHA detection and characterization}

FTIR spectroscopy is considered one of the most powerful techniques to be used to follow the kinetics of PHA production. Major functional groups and moieties in the PHB polymer were identified using a $\mathrm{KBr}$ disc on FTIR 8300 (Shimadzu spectrophotometer, Japan). Standard PHB and sample of the extracted PHA was used for comparison, $5 \mathrm{mg}$ of each were mixed with $100 \mathrm{mg}$ of FTIR grade $\mathrm{KBr}$ and pelletized. The FTIR spectra were recorded in the range of $4000-400 \mathrm{~cm}^{-1}$.

\section{GC-Mass}

PHA was qualitatively characterize using gas chromatographic analysis to monomers after methanolysis of the polymer by adding 10 $\mathrm{mg}$ of dry cell samples to $(2 \mathrm{~mL})$ of chloroform and $(2 \mathrm{~mL})$ of $15 \%$ sulfuric acid/methanol in a screw-capped tube, heated to $100{ }^{\circ} \mathrm{C}$ for 120 min. After cooling, $1 \mathrm{~mL}$ of demineralized water was added, vortexed and centrifuged for 30 min at 13,000 rpm, the organic phase containing methylester derivatives was analyzed by Agilent Technologies 7820A GC-MS System (Agilent Technologies, CA, USA) equipped with MS. The analysis was performed using a HP-5ms Ultra Inert $30 \mathrm{~m}$ x $250 \mu \mathrm{m}$ x $0.25 \mu \mathrm{m}$ column. Helium carrier gas was set at a flow rate of $1.2 \mathrm{~mL} / \mathrm{min}$. The oven temperature was programmed at $35^{\circ} \mathrm{C}$ as an initial temperature, and subsequently raised at rate of $15{ }^{\circ} \mathrm{C} / \mathrm{min}$ to $280^{\circ} \mathrm{C}$ and held for $2 \mathrm{~min}$, the total-ion scan mode at a mass-to-charge ratio $(\mathrm{m} / \mathrm{z})=40-600$ [Devi et al., 2015; Tan et al., 2014b].

\section{RESULTS AND DISCUSSIONS}

\section{Isolation and screening of the PHA producing bacteria}

A gram positive isolate (L1/a) were selected to study its ability to produce PHA. This isolate showed high growth on the PM agar medium supplemented with glucose as the only source of carbon. (Fig. 1a and Fig. 1b). The PHA detection was screened using Sudan B black staining. The L1/a bacterium showed granules filled up with black or dark blue stain. Under microscope light, the PHA granules were observed as dark spot and had a potential for PHA production (Fig. 1c and Fig. 1d). Nile Blue A staining which is another specific dye, were performed for the detection of PHA granules within the cells, a fluorescent orange granules were observed under fluorescence microscope, the intensity increased with the increase of the PHA content, indicating the presence of PHAs in the cells (Fig. 1e and Fig. 1f). Tan et al. [2014a] demonstrated that, Nile blue staining provides an evidence for the production of PHAs which enabled microbe producers to be isolated and identified. Ratnaningrum et al. [2019] stated that all the studied colonies confirmed to be able to present the cells that fluoresce under a fluorescent microscope. 
a)
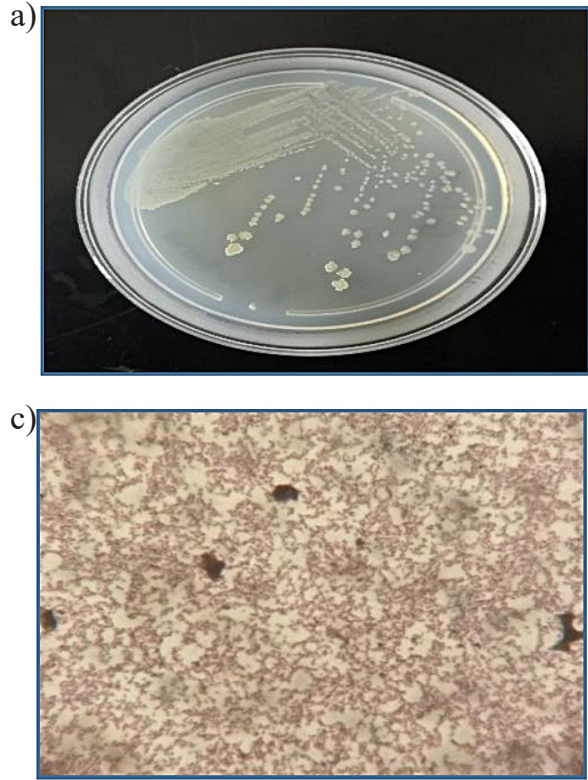

e)

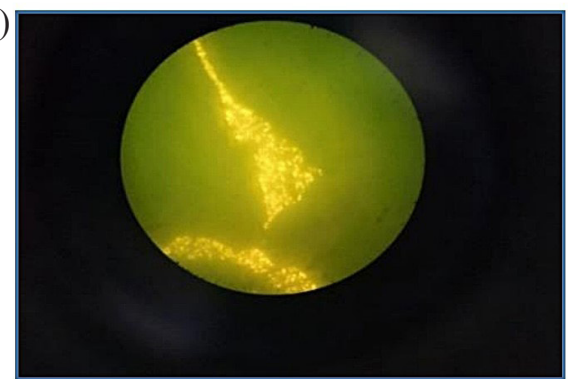

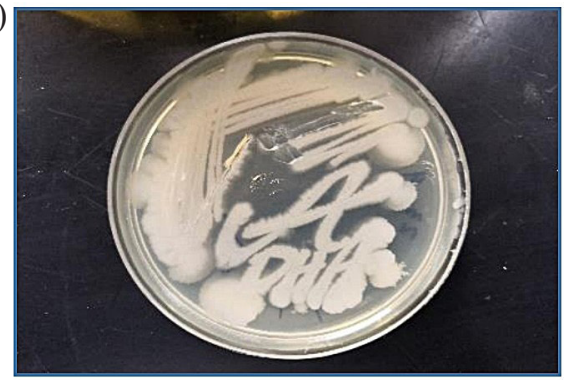

d)

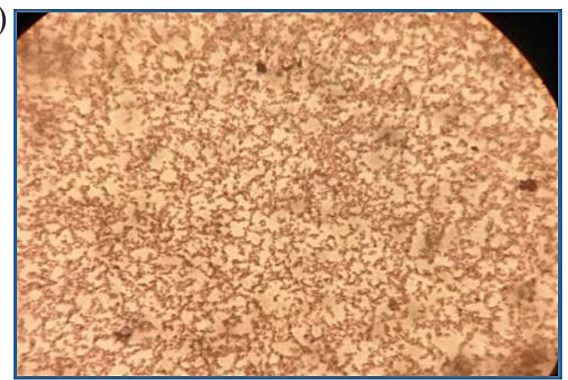

f)

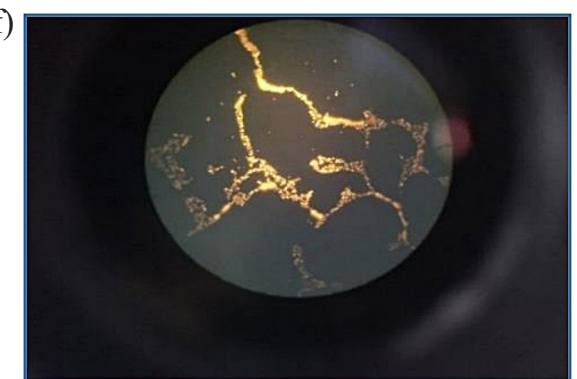

Figure 1. Staining methods for PHAs detection: $a, b)$ Isolated bacteria (L1/a) subcultured on the PM agar supplemented with $5 \%(\mathrm{w} / \mathrm{v})$ glucose at $37^{\circ} \mathrm{C}, \mathrm{pH} 7.2$ for 3 days. C, d) Sudan Black B staining observed on PHAs granules. c, d) Fluorescence microscopy of Nile Blue A, PHAs accumulation

\section{Characterization and identification of the bacterial isolates}

The bacterial isolate was initially characterized using various microbiological and biochemical tests and identified to be gram positive Bacillus spp. The data analysis performed using BLAST program to compare the 16s rRNA sequence of the isolate with the database sequences indicated that the (L1/a) bacterium gives $100 \%$ identical to that of the model strain Bacillus cereus, deposited in the NCBI GenBank database ARY73 Code MW362363. (Fig. 2a).

The phylogenetic tree was prepared based on the 16S ribosomal RNA sequences of the bacterial strain. Evolutionary analyses were conducted in MEGA-X application (Fig. 2b).

\section{Monitoring of bacterial growth and PHA yield at different carbon concentrations}

In order to study the effects of the glucose concentration over the growth of $B$. cereus strain ARY73 and PHA production, low concentrations were performed of $(\mathrm{w} / \mathrm{v}) 1.0 \%, 1.5 \%, 2.0 \%$, $2.5 \%$, and $3.0 \%$, as well as higher concentrations of $(\mathrm{w} / \mathrm{v}) 4 \%, 6 \%$ and $8 \%$. Growth was monitored every $24 \mathrm{~h}$ by measuring optical density $(600 \mathrm{~nm})$ and cell counting using the hemocytometer method, while the PHA yield was monitored after 48 and $96 \mathrm{~h}$ of incubation, respectively. (Fig. 3)

Table 1 shows a high absorbance for the low concentrations of glucose medium, $2.0 \%(\mathrm{w} / \mathrm{v})$ glucose showed highest growth OD 2.275 and cell count was $2.45 \times 10^{9}$ cells $/ \mathrm{ml}$ at $48 \mathrm{~h}$ of incubation time (stationary phase), PHA yield was 1.78 $\mathrm{g} / \mathrm{L}$ (49\% per gram CDW). The growth continued to increase slowly after $96 \mathrm{~h}$, OD was 2.586 , while cell count was $2.91 \times 10^{9}$ cells $/ \mathrm{ml}$ and maximum yield of PHA $1.98 \mathrm{~g} / \mathrm{L}$ (74\% per gram CDW), (Fig. 3c). B. cereus ARY73 gave stable growth after $48 \mathrm{~h}$, with an increase in PHA production in the glucose containing medium as the only source of carbon. A similar observation was also reported by Thammasittirong et al. [2017]. They showed that PHB accumulation was observed after $72 \mathrm{~h}$ as it served an alternative as energy source. 


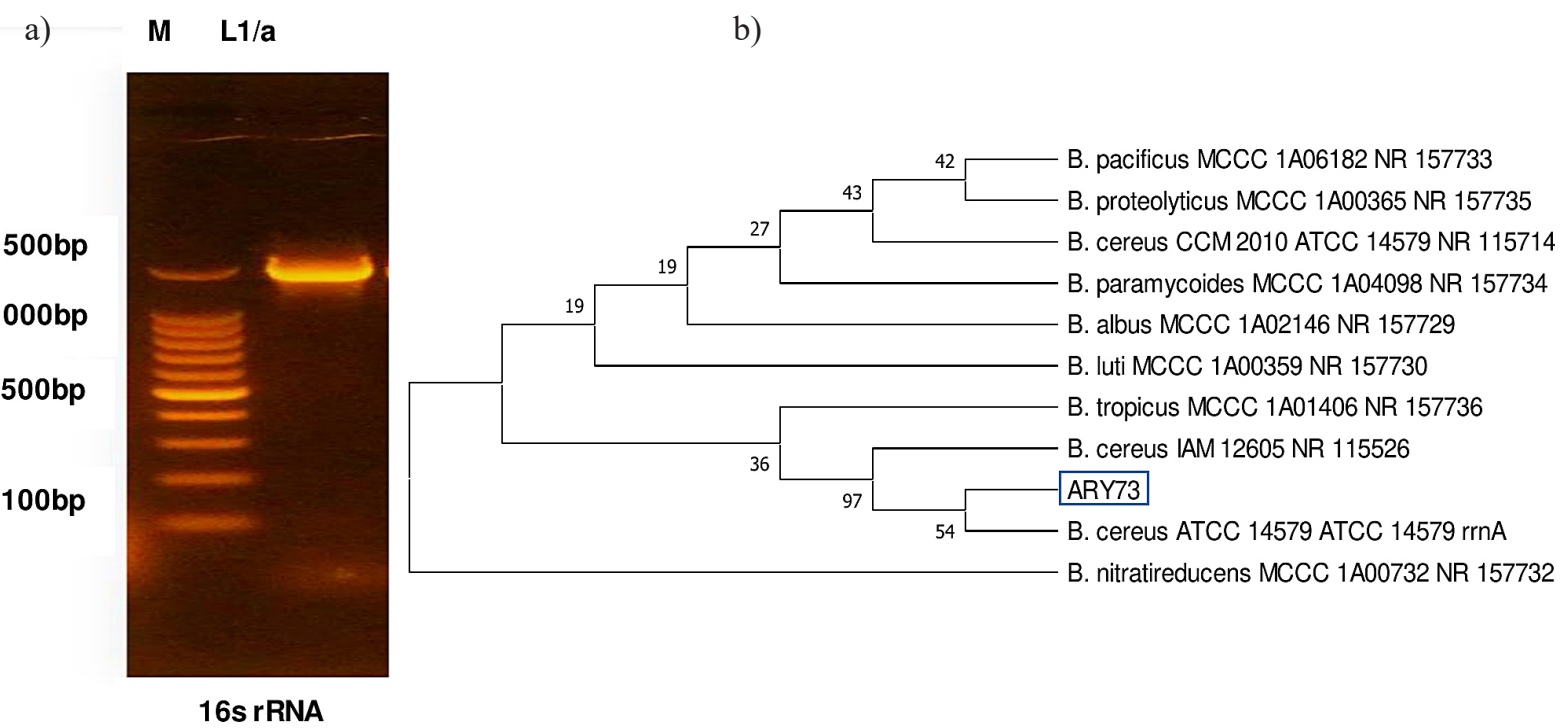

Figure 2. PCR Result. a) 16s rRNA gene with universal primers in L1/a (B. cereus ARY73). b) Phylogenetic tree of $B$. cereus strain ARY73. The bootstrap values are shown at branch nodes

For higher glucose concentrations, $4 \%(\mathrm{w} / \mathrm{v})$, $6 \%(\mathrm{w} / \mathrm{v})$ and $8 \%(\mathrm{w} / \mathrm{v})$, B. cereus ARY73 showed higher growth at $4 \%$ and maximum PHA production of about $0.64 \mathrm{~g} / \mathrm{L}(40 \%$ gm of CDW) in the glucose medium $4 \%(\mathrm{w} / \mathrm{v})$ with its ability to produce lesser quantity of PHA at $6 \%$ and $8 \%$ $(\mathrm{w} / \mathrm{v})$ concentrations. This may give an explanation that the highest concentrations of sugar can be inhibitory to the culture, decreasing its metabolic rates and affect the ability of isolate to produce PHA [Al-Kaddo et al., 2020]. Blandon et al. [2020] observed that the high values of glucose concentration give a low productivity and growth for the Bacillus sp.

Glucose consumption (DNS) by Bacillus sp. ARY73 increased rapidly after $24 \mathrm{~h}$ of incubation to record a significant decrease at $48 \mathrm{~h}$ of $1.16 \%$; in this cultivation time PHA polymerase activates as the growth and CDW increased (Fig. 3d). The glucose consumption decreased continuously in a constant rate recording lowest value of $0.95 \%$ after $96 \mathrm{~h}$ with high production of PHA (1.98 $\mathrm{g} / \mathrm{L})$. The PHA production decreased as nutrients depletion in medium resulting in the exhaustion of PHA using PHA depolymerase.

\section{Effect of temperature and initial $\mathrm{pH}$ on the PHA production}

The PHA production extracted from dry biomass and glucose consumption (Fig. 3a and Fig. $3 \mathrm{~b})$ was measured after 48 and $96 \mathrm{~h}$ of incubation at an optimized glucose concentration (2\%). B. cereus ARY73 showed a clear PHA production in the range of 30 to $35^{\circ} \mathrm{C}$, the highest PHA content was obtained at $35^{\circ} \mathrm{C}$ of $2.61 \mathrm{~g} / \mathrm{L}(\mathrm{PHA} 76 \%$ ) after $96 \mathrm{~h}$ of

Table 1. Growth kinetics of B. cereus ARY73 isolate at low and high glucose concentrations during 24-96 h of incubation and CDW at 48 and $96 \mathrm{~h}$. Illustrate the maximum yield of PHA production at $2.0 \%$ of glucose concentration. $($ Control OD $=0.1)$

\begin{tabular}{|c|c|c|c|c|c|c|c|c|c|c|}
\hline \multirow{2}{*}{$\begin{array}{c}w(\text { Glucose }) / \\
(\%)_{(\mathrm{w} / \mathrm{v})}\end{array}$} & \multirow{2}{*}{$\begin{array}{c}t / 24 \mathrm{~h} \\
\mathrm{OD} \\
(600 \mathrm{~nm})\end{array}$} & \multicolumn{4}{|c|}{$t / 48 \mathrm{~h}$} & \multirow{2}{*}{$\begin{array}{c}t / 72 \mathrm{~h} \\
\mathrm{OD} \\
(600 \mathrm{~nm})\end{array}$} & \multicolumn{4}{|c|}{$t / 96 \mathrm{~h}$} \\
\hline & & $\begin{array}{c}\mathrm{OD} \\
(600 \mathrm{~nm}) \\
\end{array}$ & $\begin{array}{c}(\mathrm{CDW}) / \\
(\mathrm{g} / \mathrm{L})\end{array}$ & $\begin{array}{c}(\mathrm{PHA}) / \\
(\mathrm{g} / \mathrm{L}) \\
\end{array}$ & $\begin{array}{c}(\mathrm{PHA}) / \\
(\%)\end{array}$ & & $\begin{array}{c}\mathrm{OD} \\
(600 \mathrm{~nm}) \\
\end{array}$ & $\begin{array}{c}(\mathrm{CDW}) / \\
(\mathrm{g} / \mathrm{L}) \\
\end{array}$ & $\begin{array}{c}(\mathrm{PHA}) / \\
(\mathrm{g} / \mathrm{L})\end{array}$ & $\begin{array}{l}(\mathrm{PHA}) / \\
(\%)_{(\mathrm{w} / \mathrm{V})}\end{array}$ \\
\hline 1.0 & 1.868 & 2.636 & 3.84 & - & - & 1.556 & 1.476 & 1.16 & - & - \\
\hline 1.5 & 1.678 & 2.157 & 3.05 & 1.18 & 38 & 2.308 & 2.143 & 1.83 & 0.98 & 53 \\
\hline 2.0 & 1.849 & 2.275 & 3.61 & 1.78 & 49 & 2.644 & 2.586 & 2.67 & 1.98 & 74 \\
\hline 2.5 & 1.766 & 1.772 & 1.65 & 0.61 & 37 & 2.036 & 2.243 & 1.90 & 1.08 & 57 \\
\hline 3.0 & 1.532 & 1.482 & 1.27 & 0.39 & 31 & 1.566 & 1.572 & 1.22 & 0.42 & 34 \\
\hline 4.0 & 1.187 & 2.445 & 1.61 & 0.64 & 40 & 2.508 & 2.215 & 1.33 & - & - \\
\hline 6.0 & 1.222 & 2.343 & 1.28 & 0.41 & 32 & 2.343 & 1.954 & 1.21 & - & - \\
\hline 8.0 & 1.410 & 2.403 & 1.0 & - & - & 2.271 & 1.843 & 0.76 & - & - \\
\hline
\end{tabular}


a)
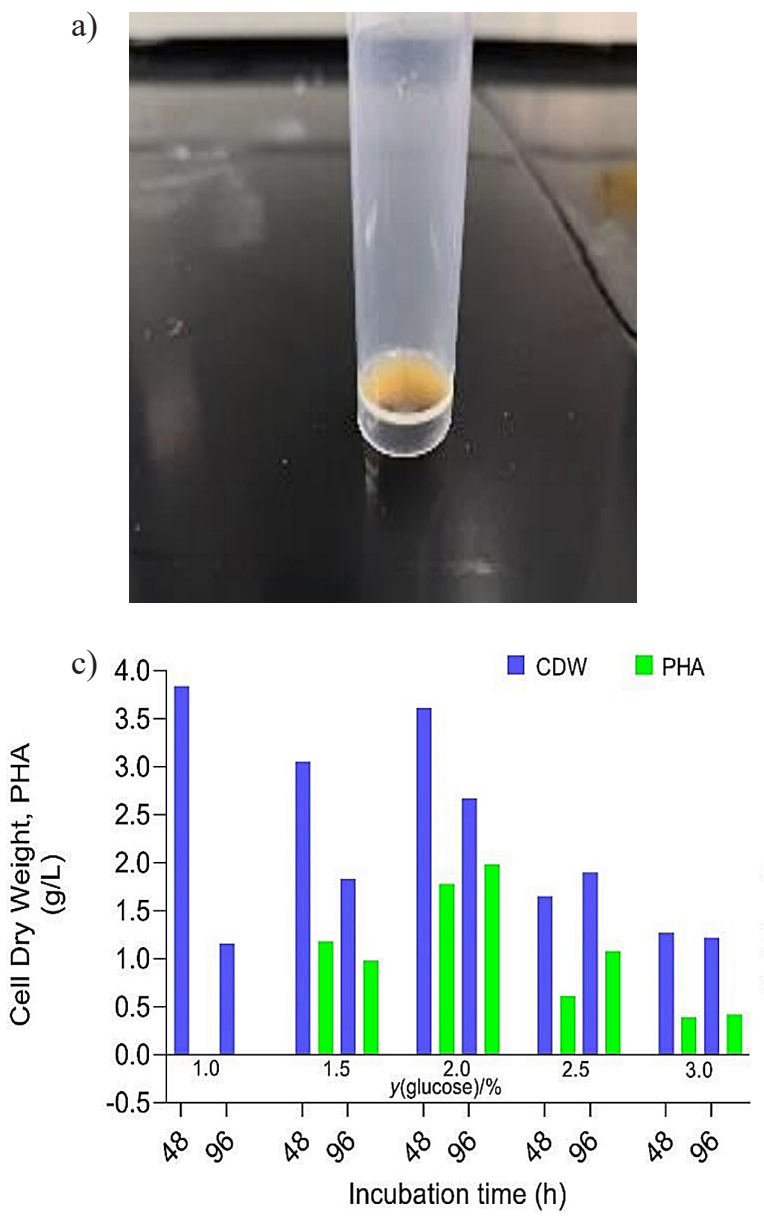

b)

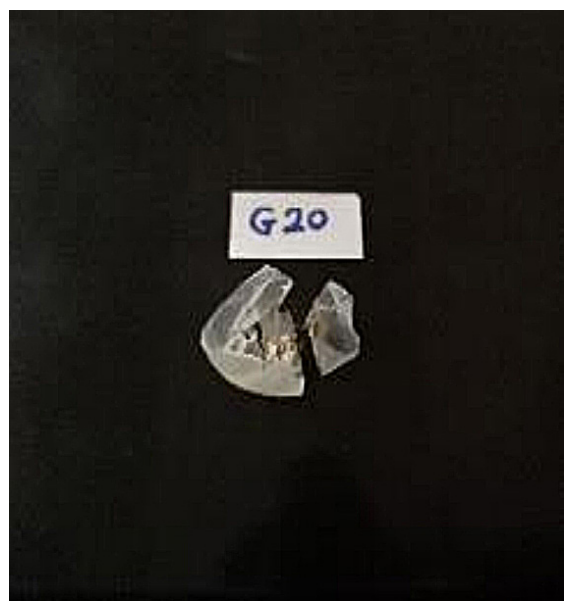

d)

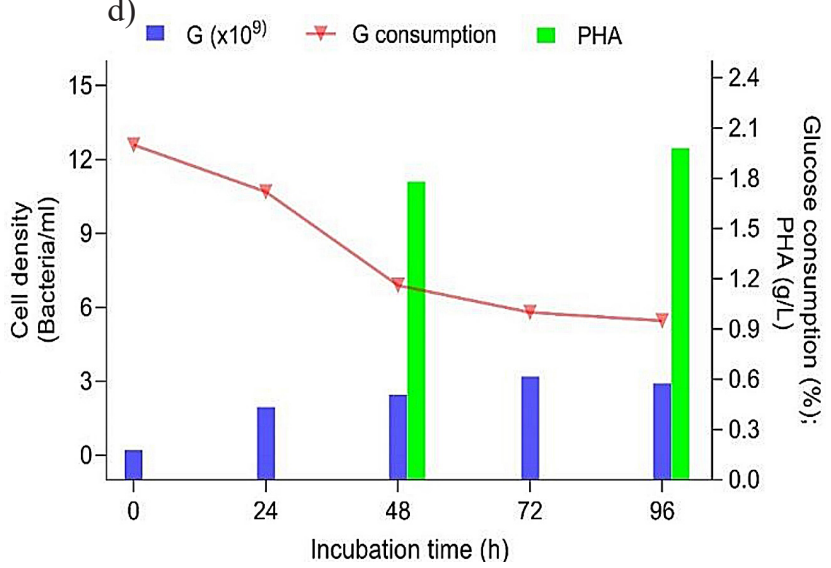

Figure 3. Effects of different glucose concentrations on the growth and PHA production by B. cereus ARY73: a) Cell biomass, b) Extracted PHA, c) Optimized glucose concentration, PHA yield for 48 and 96 h, d) Sugar consumption (DNS) with highest PHA yield using 2\% (w/v) glucose

incubation, DNS of glucose was $1.36 \%$ (Fig. 4a). No PHA production occurred at $40{ }^{\circ} \mathrm{C}$, while the strain was able to grow with a Cell Dry Weight of 3.41 and $2.51 \mathrm{~g} / \mathrm{L}$ at 48 and $96 \mathrm{~h}$, respectively, this indicates that the higher the Cell Dry Weight does not necessarily imply an increase in PHA production. Javaid et al. [2020] demonstrated that the Stenotrophomonas maltophilia strain IAM 12423 showed poor decline in PHA yield at a temperature above $37{ }^{\circ} \mathrm{C}$, while still recorded high amount of CDW.

The other important factor affecting the growth of Bacillus spp. and its ability to produce PHA is the $\mathrm{pH}$. In order to study the response of isolate to $\mathrm{pH}$, B. cereus ARY73 was grown at different $\mathrm{pH}(5$, 7 and 9$)$ and best temperature $\left(35^{\circ} \mathrm{C}\right)$ for $96 \mathrm{~h}$, then the PHA production was measured (Fig. 7b). This strain produced maximum amount of PHA at $\mathrm{pH}$ 7 on the days 48 and $96 \mathrm{~h}$ which was $2.65 \mathrm{~g}$ (71\% of CDW) and $2.74 \mathrm{~g}(74 \%$ of CDW), respectively (Fig. 4b). Increasing $\mathrm{pH}$ to 9 decreased the production of PHA, the PHA production amounted to 0.48 $\mathrm{g}(33 \%$ of CDW $)$ and $0.44 \mathrm{~g}(36 \%$ of CDW $)$ for 48 and $96 \mathrm{~h}$, respectively. On the other hand, decreasing $\mathrm{pH}$ to 5 prevented $B$. cereus ARY73 producing PHA, which may indicate that this strain could grow and produce PHA in neutral $\mathrm{pH}$ as a favored $\mathrm{pH}$, while it can also produce it in less amounts in the alkaline medium ( $\mathrm{pH}$ 9) in contrast to an acidic medium [Tan et al., 2014]. It is clear from the data in Figure 4a and Figure 4b that the glucose concentration was decreased as the PHA production increased during incubation time, this gives a fact that B. cereus ARY73 exploited abundance glucose to produce the PHA polymer and for other metabolic requirements.

\section{Effect of Nitrogen Source Concentration on PHA production}

The effect of various nitrogen concentrations in both media on the PHA production by the two isolates were investigated. Figure 5 illustrates that the, B. cereus ARY73 biomass showed higher PHA production at the concentrations (w/v) of $0.75 \%$ and 
a)
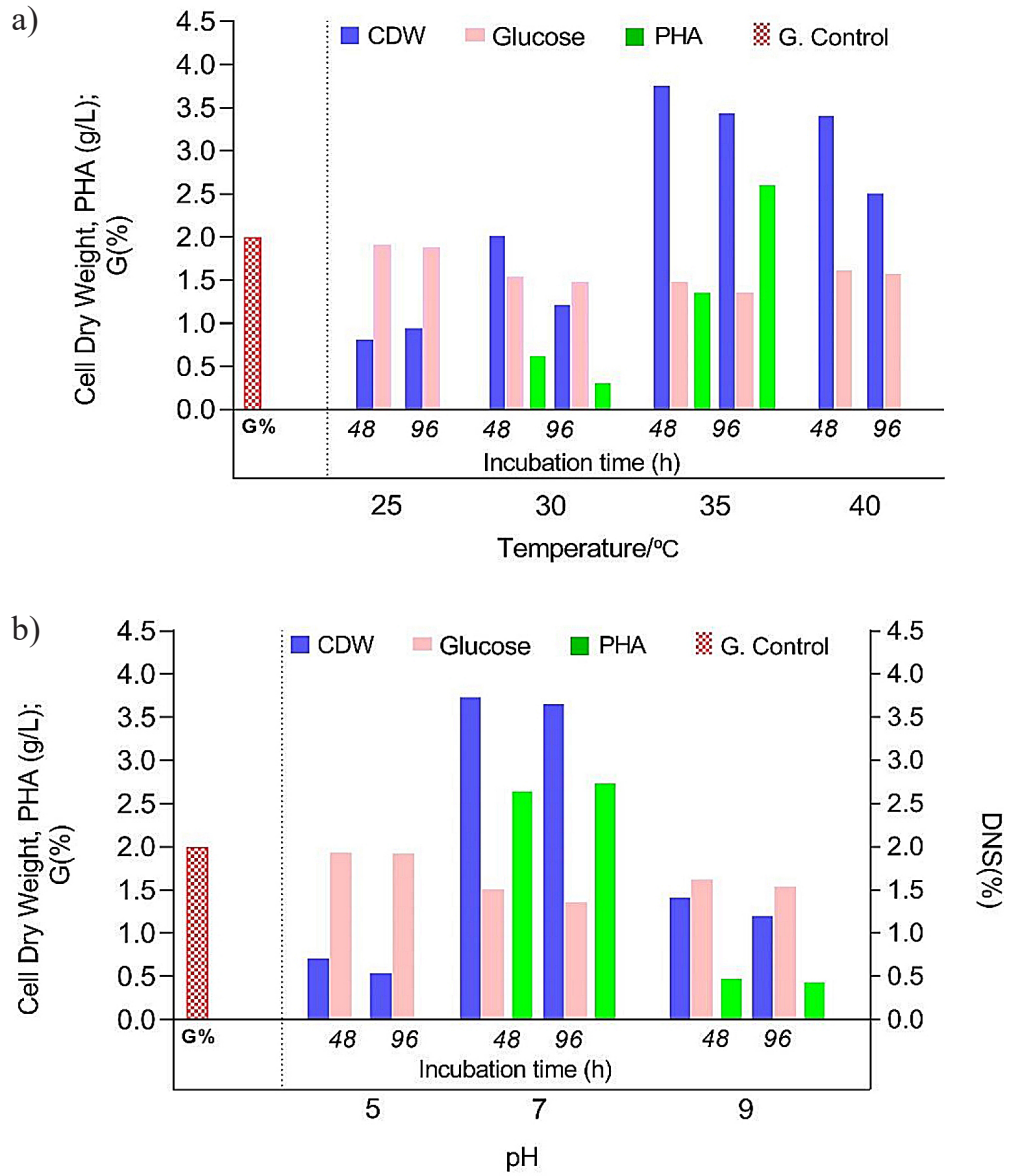

Figure 4. PHA production, $\mathrm{CDW}(\mathrm{g} / \mathrm{L})$ and glucose content values (DNS\%) by B. cereus ARY73 during 48 and $96 \mathrm{~h}$ of incubation, in response to: a) Different temperatures $25,30,35$ and $40{ }^{\circ} \mathrm{C}$, glucose $2 \%(\mathrm{w} / \mathrm{v})$. b) $\mathrm{pH} 5,7$ and 9 at favorite temperature $35^{\circ} \mathrm{C}$ and glucose $2 \%(\mathrm{w} / \mathrm{v})$

$1 \%$ of nitrogen tested $2.87 \mathrm{~g} / \mathrm{L}$ (PHA 77\%) and 2.34 g/L (PHA 79\%) respectively. The low nitrogen concentration $(0.5 \% \mathrm{w} / \mathrm{v})$ decreased the PHA production and limit the amount of CDW. This indicates that the nitrogen concentrations over the average $(0.5-1 \% \mathrm{w} / \mathrm{v})$ decreased the PHA production.

These results also supported by Campos et al. [2014], who studied the influence of crude glycerin and nitrogen concentrations on the PHA production by Cupriavidus necator; they found that the limited nitrogen concentration is essential for PHA production while low and high concentrations lowered it. The extracted PHA by the B. cereus strain ARY73 was cultivated under favorite conditions $[2 \%(\mathrm{w} / \mathrm{v})$ $\left.\mathrm{G}, \mathrm{pH} 7,35^{\circ} \mathrm{C}, 1 \% \mathrm{~N}\right]$ is shown in Figure $5 \mathrm{~b}$.

\section{PHA Characteristics}

\section{FTIR analysis for PHA detection and characterization}

All samples were analyzed by FTIR spectroscopy to characterize the PHA by identifying the functional groups. PHB standard (BASF ecovio, Germany) and the PHA extracted from B. cereus ARY73 were used for comparison (Fig. 6). Strong peaks were at $1726.17 \mathrm{~cm}^{-1}$ indicates the presence of $\mathrm{C}=\mathrm{O}$ ester bond. Similar results were reported by Paul et al. [2017], they mentioned that the peaks between 1718 and $1735 \mathrm{~cm}^{-1}$ are for ester stretch bands $(\mathrm{C}=\mathrm{O})$ [Sasikumar and Balakumaran, 2017]. In addition, the bands between $\sim 1643.24$ and $1278.72 \mathrm{~cm}^{-1}$ are due to the presence of $\mathrm{C}=\mathrm{O}$ and $\mathrm{C}-\mathrm{O}$ stretching groups. The peaks obtained between 1456.16 and $1380.94 \mathrm{~cm}^{-1}$ correspond to the asymmetric and symmetric stretching $\mathrm{C}-\mathrm{H}$ bond in the methylene group, also the peaks between $\sim 2962.46$ and $2877.60 \mathrm{~cm}^{-1}$ originated by $\mathrm{C}-\mathrm{H}$ in methylene group $\mathrm{O}-\mathrm{H}$ group [Sawant et al. 2017]. Compared with PHB standard, the strongest vibrations near $2933 \mathrm{~cm}^{-1}$ indicated to Scl-co-mcl PHA [Shamala et al. 2009]. MCL-PHA can offer a wide range of applications due to their physical and chemical properties that come from the fact they can bear different functional groups in the side chains [Rigouin et al. 2019]. 

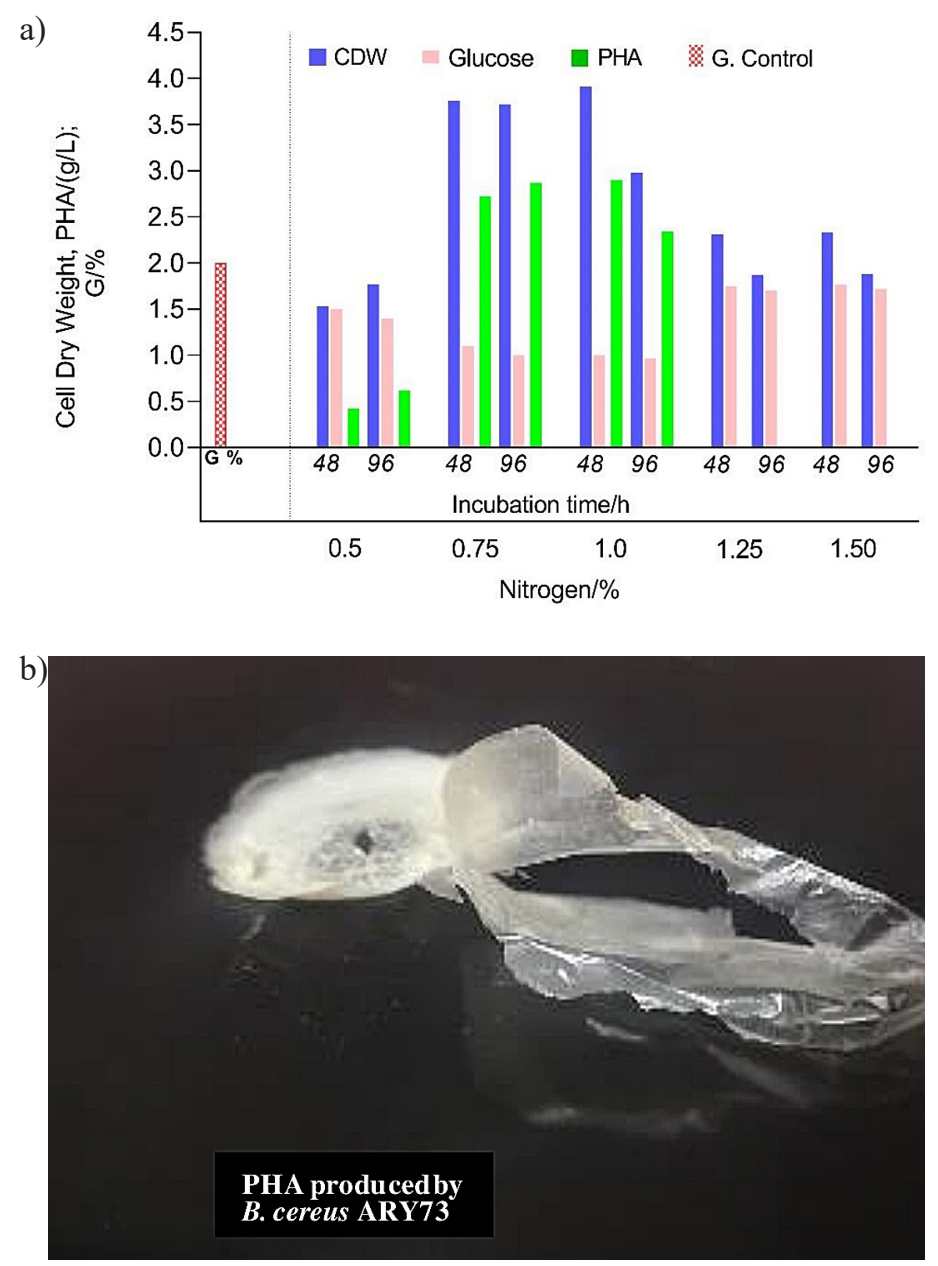

Figure 5. a) Favorite nitrogen concentrations ( 0.75 and $1.0 \%)$ for the PHA production by the $B$. cereus ARY73 strain, illustrating the amount of Cell Dry Weight (CDW) and glucose consumption (DNS) on incubation time 48 and $96 \mathrm{~h}$. [Glucose $2 \%(\mathrm{w} / \mathrm{v}) ; 35^{\circ} \mathrm{C} ; \mathrm{pH}$ 7],

b) the PHA extracted from $B$. cereus ARY73 cultivated under favorite conditions

The strong peak between 1278.72 and $1228.57 \mathrm{~cm}^{-1}$ corresponding to asymmetric stretch of C-O-C group indicated the presence of an ester bond due to the $\mathrm{C}-\mathrm{H}$ group in biopolymer [Vieira et al., 2011]. On the other hand, the peaks at 1182.28 and $1056.92 \mathrm{~cm}^{-1}$ are expected for the ether stretch (C-O-C) and dioxane bands, respectively, in which the presence of 3-hydroxybutyrate units (scl-PHA) may be confirmed. The bands of dioxane were observed at $1056.92 \mathrm{~cm}^{-1} \mathrm{C}-\mathrm{O}-\mathrm{C}$ symmetric stretching. The presence of the peak at 3434.98 $\mathrm{cm}^{-1}$ may be due to the terminal $\mathrm{O}-\mathrm{H}$ bonding or water adsorption on the PHB [Hassan et al., 2016].

\section{GC-Mass}

In order to determine the PHA content and monomeric composition within the $B$. cereus ARY73 isolate, the GC-MS data was evaluated after acidic methanolysis of dried cells. Figure 11 showed that, two peaks were detected with a retention time $(\mathrm{Rt})$ values of 6.305 and $6.185 \mathrm{~min}$ (Area 1) corresponding to PHB (3-hydroxybutyric acid) as scl-PHA monomers and the Rt values of 9.718 and 9.873 min (Area 2) as mcl-PHA (3-hydroxyoctanoic acid) with some derivative products - methyl ester, 2-pentenoic acid, trifluoroacetate, hydroxyoctanoic acid, 2,3,4-Trimethyl-2-pentene (which is formed during the copolymerization). Bacillus spp. are among a few (wild-type) bacteria that can synthesize and accumulate $\mathrm{P}(3 \mathrm{HASCL}-\mathrm{co}-3 \mathrm{HAMCL})$, this research proved that the $B$. cereus ARY73 strain was able to produce scl-mcl-PHA as a rare strain comparing to the same species mentioned in previous publications. Gram-positive bacteria lack lipopolysaccharides (LPS) endotoxin which may make them better sources of PHAs for use in biomedical applications [Sawant et al., 2017].

The observed RTs peaks of Area ( 1 and 2) methyl esters derived from both PHA and 

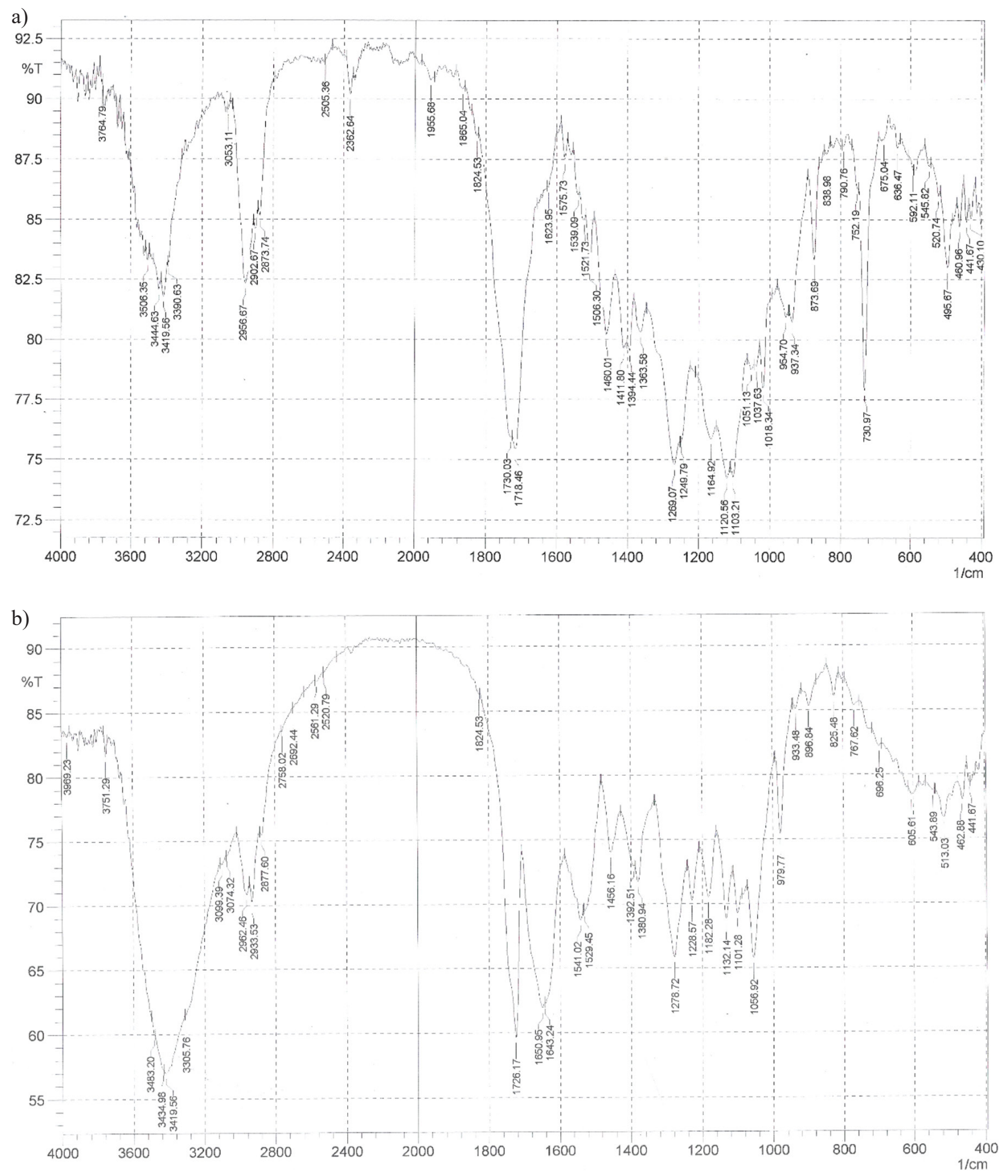

Figure 6. FTIR spectrum of PHAs: (a) Standard PHB; (b) PHA extracted from B. cereus ARY73

PHAHV were similar comparing to that observed from the PHA monomer of synthesized sample (control), with a strong peak noticed at Area 1.

\section{CONCLUSIONS}

In the current study, a bacterial strain was isolated from a garden soil located in the city of Baghdad-Iraq, the ability of this isolate to produce PHA was determined using staining methods (Sudan B Black stain and Nile Blue A stain). The results showed abundance of accumulated intracellular PHA granules in bacteria. The best conditions for the growth and PHA production by $B$. cereus ARY73 were examined, $2 \%(\mathrm{w} / \mathrm{w})$ glucose was the best concentration (yield 74\% PHA per gram CDW). It was also found that this isolate was able to grow and produce polymer at concentrations ranging between 


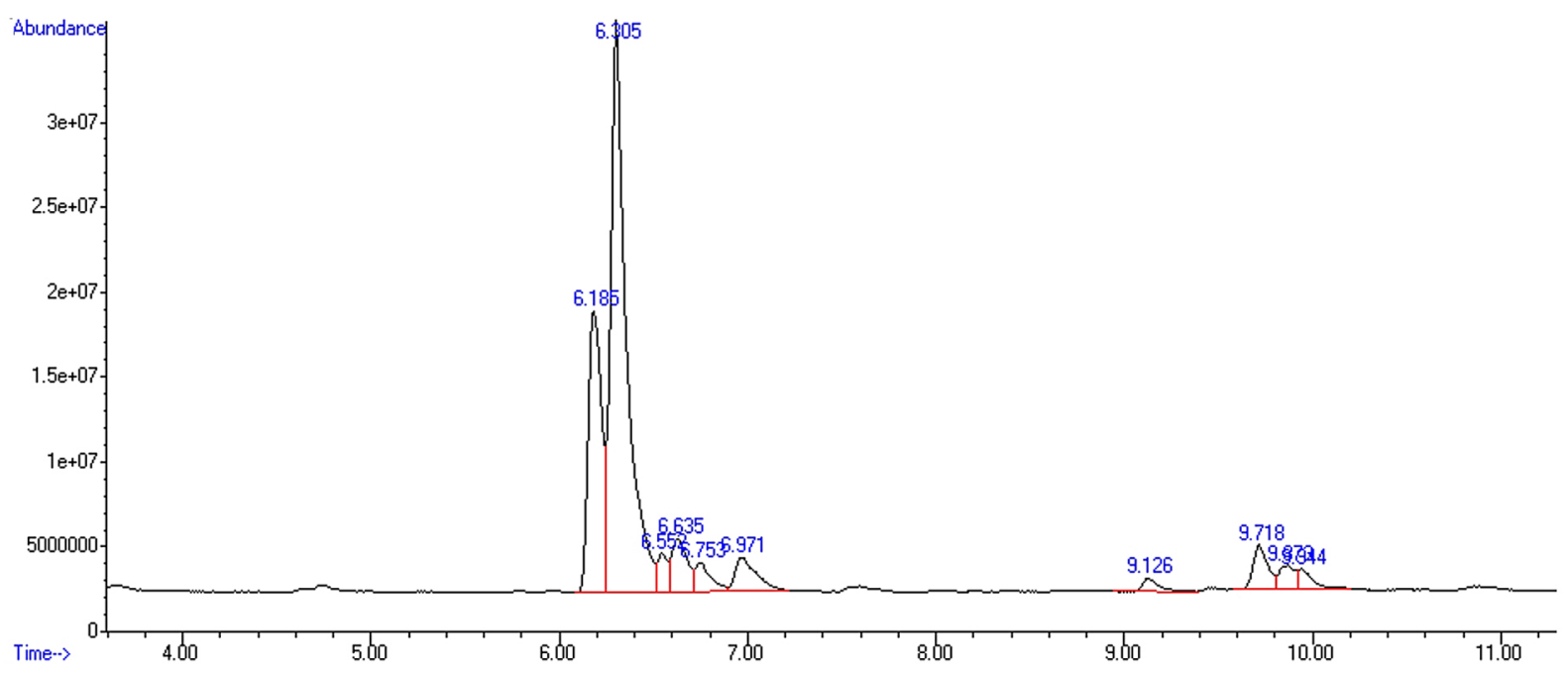

Figure 7. GC-MS analysis result of PHA obtained from B. cereus ARY73

4-6\%, but in lesser amounts, together with other best fermenting conditions (temperature $35^{\circ} \mathrm{C}$, $\mathrm{pH} 7$, and $1 \% \mathrm{~N}$ ). The PHA produced by B. cereus ARY73 was analyzed by FTIR and GC-MS, indicating the (Scl-co-mcl) co-polymer PHA structure which is suitable for diverse applications. The strain ARY73 was submitted to the NCBI GenBank database with the accession number of MW362363. Further extensive research into using variant biopolymer products within different site of soils for the isolation of PHA producing bacteria, and investigate its ability to produce PHA (individually or mixed bacteria) are highly recommended. Genetic modification of bacteria to improve the production of biopolymers is recommended for further study.

\section{Acknowledgements}

I express my sincere gratitude to Prof. Dr. Ithar Kamil Al-Mayali from Biology Department-University of Baghdad, for her important considerations and providing necessary materials. Also, I would like to thank all professors from the Biology Department for their supports. Finally, I dedicate this work to my loving family for their constant support and encouragement.

\section{REFERENCES}

1. Al-Kaddo, K.B., Mohamad, F., Murugan, P., Tan, J.S., Sudesh, K., Samian, M.R. 2020. Production of P(3HBco-4HB) copolymer with high $4 \mathrm{HB}$ molar fraction by Burkholderia contaminans Kad1 PHA synthase. Biochemical Engineering Journal, 153, 107394.
2. Pillai, A.B., Kumar, A.J., Kumarapillai, H. 2018. Enhanced production of poly(3-hydroxybutyrate) in recombinant Escherichia coli and EDTA-microwave-assisted cell lysis for polymer recovery. AMB Express, 8(1), 142.

3. Blandón, L., Alvarado-Campo, K.L., Patiño, A.D., Jiménez-Vergara, E., Quintero, M., Montoya-Giraldo, M., Jutinico-Shubach, L.M., Santos-Acevedo, M., Gómez-León, J. 2020. Polyhydroxyalkanoate Production from Two Species of Marine Bacteria: A Comparative Study. Journal of Polymers and the Environment, 28(9), 2324-2334.

4. Devi, A.B., Nachiyar, C.V., Kaviyarasi, T., Samrot, A.V. 2015. Characterization of polyhydroxybutyrate synthesized by Bacillus Cereus. International Journal of Pharmacy and Pharmaceutical Sciences, 7(3), 140-144.

5. Campos, M.I., Figueiredo, T.V.B., Sousa, L.S., Druzian, J.I. 2014. The influence of crude glycerin and nitrogen concentrations on the production of PHA by Cupriavidus necator using a response surface methodology and its characterizations. Industrial Crops and Products, 52, 338-346.

6. Chee, J.Y., Lau, N.S., Samian, M.R., Tsuge, T., Sudesh, K. 2012. Expression of Aeromonas caviae polyhydroxyalkanoate synthase gene in Burkholderia sp. USM (JCM15050) enables the biosynthesis of SCL-MCL PHA from palm oil products. Journal of Applied Microbiology, 112(1), 45-54.

7. Franz, A., Rehner, R., Kienle, A., Grammel, H. 2012. Rapid selection of glucose-utilizing variants of the polyhydroxyalkanoate producer Ralstonia eutropha $\mathrm{H} 16$ by incubation with high substrate levels. Letters in Applied Microbiology, 54(1), 45-51.

8. Getachew, A. \& Woldesenbet, F. 2016. Production of biodegradable plastic by polyhydroxybutyrate (PHB) accumulating bacteria using low cost agricultural waste material. BMC Research Notes, 9(1), 509. 
9. Hassan, M., Bakhiet, E., Ali, S., Hussien, H. 2016. Production and characterization of polyhydroxybutyrate (PHB) produced by Bacillus sp. isolated from Egypt. Journal of Applied Pharmaceutical Science, 6(4), 046-051.

10. Javaid, H., Nawaz, A., Riaz, N., Mukhtar, H., U1Haq, I., Shah, K.A., Khan, H., Naqvi, S.M., Shakoor, S., Rasool, A. 2020. Biosynthesis of Polyhydroxyalkanoates (PHAs) by the Valorization of Biomass and Synthetic Waste. Molecules, 25(23), 5539.

11. Johnson, M., Zaretskaya, I., Raytselis, Y., Merezhuk, Y., McGinnis, S., Madden, T.L. 2008. NCBI BLAST: a better web interface. Nucleic acids research, 36(suppl_2), W5-W9.

12. Kamravamanesh, D., Lackner, M., Herwig, C. 2018. Bioprocess engineering aspects of sustainable polyhydroxyalkanoate production in cyanobacteria. Bioengineering, 5(4), 111.

13. Kearse, M., Moir, R., Wilson, A., Stones-Havas, S., Cheung, M., Sturrock, S., Buxton, S., Cooper, A., Markowitz, S., Duran, C. 2012. Geneious Basic: an integrated and extendable desktop software platform for the organization and analysis of sequence data. Bioinformatics, 28(12), 1647-1649.

14. Khosravi-Darani, K., Mokhtari, Z.B., Amai, T., Tanaka, K. 2013. Microbial production of poly(hydroxybutyrate) from C1 carbon sources. Applied Microbiology and Biotechnology, 97(4), 1407-1424.

15. Koller, M. 2018. Biodegradable and Biocompatible Polyhydroxy-alkanoates (PHA): Auspicious Microbial Macromolecules for Pharmaceutical and Therapeutic Applications. Molecules, 23(2), 362.

16. Kourmentza, C., Plácido, J., Venetsaneas, N., Burniol-Figols, A., Varrone, C., Gavala, H.N., Reis, M.A.M. 2017. Recent advances and challenges towards sustainable polyhydroxyalkanoate (PHA) production. Bioengineering, 4(2), 55.

17. Legat, A., Gruber, C., Zangger, K., Wanner, G., Stan-Lotter, H. 2010. Identification of polyhydroxyalkanoates in Halococcus and other haloarchaeal species. Applied Microbiology and Biotechnology, 87(3), 1119-1127.

18. Mezzolla, V., D’Urso, O.F., Poltronieri, P. 2017. Optimization of polyhydroxyalkanoate production by recombinant E. coli supplemented with different plant by-products. Biotechnol. Indian J, 13, 138.

19. Mezzolla, V., D’Urso, O.F., Poltronieri, P. 2018. Role of PhaC type I and type II enzymes during PHA biosynthesis. Polymers, 10(8), 910.

20. Miller, G.L. 1959. Use of Dinitrosalicylic Acid Reagent for Determination of Reducing Sugar. Analytical Chemistry, 31(3), 426-428.

21. Mitra, R., Xu, T., Xiang, H., Han, J. 2020. Current developments on polyhydroxyalkanoates synthesis by using halophiles as a promising cell factory. Microbial Cell Factories, 19(1), 1-30.
22. Napathorn, S.C. 2014. Biocompatibilities and biodegradation of poly(3-hydroxybutyrate-co-3-hydroxyvalerate)s produced by a model metabolic reaction-based system. BMC Microbiology, 14(1), 285.

23. Ojha, N., Das, N. 2020. Process optimization and characterization of polyhydroxyalkanoate copolymers produced by marine Pichia kudriavzevii VIT-NN02 using banana peels and chicken feather hydrolysate. Biocatalysis and Agricultural Biotechnology, 27, 101616.

24. Pagliano, G., Ventorino, V., Panico, A., Pepe, O. 2017. Integrated systems for biopolymers and bioenergy production from organic waste and by-products: A review of microbial processes. Biotechnology for Biofuels, 10(1).

25. Paul, S., Sasikumar, S.C., Balakumaran, M.D. 2017. Optimization, purification and characterization of polyhydroxybutyrate (PHB) produced by Bacillus cereus isolated from sewage. International Journal of Chem Tech Research, 10(7), 884-904.

26. Poltronieri, P., Kumar, P. 2017. Polyhydroxyalkanoates (PHAs) in industrial applications. Handbook of Ecomaterials. Cham: Springer International Publishing, 1-30.

27. Radivojevic, J., Skaro, S., Senerovic, L., Vasiljevic, B., Guzik, M., Kenny, S.T., Maslak, V., NikodinovicRunic, J., O’Connor, K.E. 2016. Polyhydroxyalkanoate-based 3-hydroxyoctanoic acid and its derivatives as a platform of bioactive compounds. Applied Microbiology and Biotechnology, 100(1), 161-172.

28. Ratnaningrum, D., Saraswaty, V., Priatni, S., Lisdiyanti, P., Purnomo, A., Pudjiraharti, S. 2019. Screening of polyhydroxyalkanoates (PHA)-producing bacteria from soil bacteria strains. In IOP Conference Series: Earth and Environmental Science, pp. 12003. IOP Publishing.

29. Riaz, S., Rhee, K.Y., Park, S.J. 2021. Polyhydroxyalkanoates (PHAs): Biopolymers for Biofuel and Biorefineries. Polymers, 13(2), 253.

30. Rigouin, C., Lajus, S., Ocando, C., Borsenberger, V., Nicaud, J.M., Marty, A., Avérous, L., Bordes, F. 2019. Production and characterization of two medium-chain-length polydroxyalkanoates by engineered strains of Yarrowia lipolytica. Microbial Cell Factories, 18(1), 99.

31. Sawant, S., Salunke, B., Taylor, L., Kim, B. 2017. Enhanced Agarose and Xylan Degradation for Production of Polyhydroxyalkanoates by Co-Culture of Marine Bacterium, Saccharophagus degradans and Its Contaminant, Bacillus cereus. Applied Sciences, 7(3), 225.

32. Shamala, T.R., Divyashree, M.S., Davis, R., Kumari, K.S.L., Vijayendra, S.V.N., Raj, B. 2009. Production and characterization of bacterial polyhydroxyalkanoate copolymers and evaluation of their blends by fourier transform infrared spectroscopy and scanning electron microscopy. Indian Journal of Microbiology, 49(3), 251-258. 
33. Shrivastav, A., Mishra, S.K., Pancha, I., Jain, D., Bhattacharya, S., Patel, S., Mishra, S. 2011. Biodegradability studies of polyhydroxyalkanoate (PHA) film produced by a marine bacteria using Jatropha biodiesel byproduct as a substrate. World Journal of Microbiology and Biotechnology, 27(7), 1531-1541.

34. Singh Saharan, B., Grewal, A., Kumar, P. 2014. Biotechnological Production of Polyhydroxyalkanoates: A Review on Trends and Latest Developments. Chinese Journal of Biology, 2014, 1-18.

35. Surendran, A., Lakshmanan, M., Chee, J.Y., Sulaiman, A.M., Thuoc, D.V., Sudesh, K. 2020. Can Polyhydroxyalkanoates Be Produced Efficiently From Waste Plant and Animal Oils? Frontiers in Bioengineering and Biotechnology, 8, 169.

36. Tan, G.Y., Chen, C.L., Li, L., Ge, L., Wang, L., Razaad, I., Li, Y., Zhao, L., Mo, Y., Wang, J.Y. 2014a. Start a Research on Biopolymer Polyhydroxyalkanoate (PHA): A Review. Polymers, 6(3), 706-754.

37. Tan, G.Y.A., Chen, C.L., Ge, L., Li, L., Wang, L., Zhao, L., Mo, Y., Tan, S.N., Wang, J.Y. 2014b. Enhanced gas chromatography-mass spectrometry method for bacterial polyhydroxyalkanoates analysis. Journal of Bioscience and Bioengineering, 117(3), 379-382.
38. Thammasittirong, A., Saechow. S., Thammasittirong, S.N.R. 2017. Efficient polyhydroxybutyrate production from Bacillus thuringiensis using sugarcane juice substrate. Turkish Journal of Biology, 41(6), 992-1002.

39. Mohan, S.V., Reddy, M.V., Subhash, G.V., Sarma, P.N. 2010. Fermentative effluents from hydrogen producing bioreactor as substrate for poly $(\beta-\mathrm{OH})$ butyrate production with simultaneous treatment: An integrated approach. Bioresource Technology, 101(23), 9382-9386.

40. Vieira, M.G.A., da Silva, M.A., dos Santos, L.O., Beppu, M.M. 2011. Natural-based plasticizers and biopolymer films: A review. European Polymer Journal, 47(3), 254-263.

41. Vogel, F.A. de, Schlundt, C., Stote, R.E., Ratto, J.A., Amaral-Zettler, L.A. 2021. Comparative genomics of marine bacteria from a historically defined plastic biodegradation consortium with the capacity to biodegrade polyhydroxyalkanoates. Microorganisms, 9(1), 186.

42. Yasin, A.R., Al-Mayaly, I.K. 2020. Isolation and identification of polyhydroxyalkanoates producing bacteria from biopolymers waste in soil. In IOP Conference Series: Materials Science and Engineering, pp. 62014. IOP Publishing. 